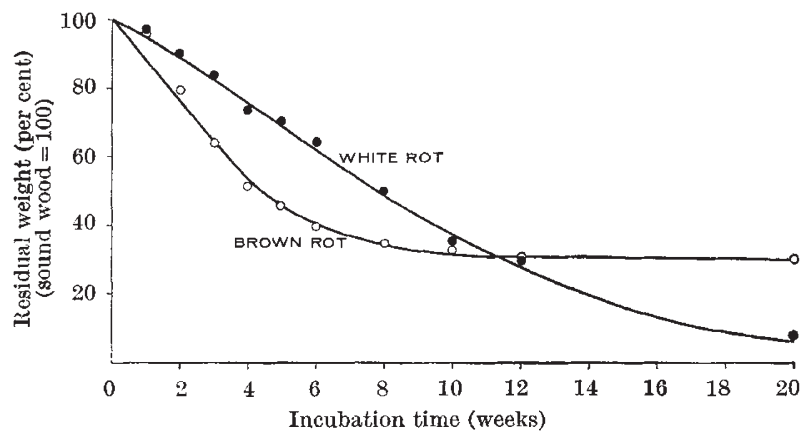

Fig. 1. Fit of equation (9) with Wilcox's data for the average residual weights of sweetgum wood samples during incubation with fungus. Points refer to Wilcox's data. Solid lines were drawn using equation (9).

equation (9) which will allow for preservative effects in different ways. A repetition of Wilcox's experiments using preserved wood would yield more appropriate kinetic data.

Saginaw Valley College,

T. Gullespie

University Center, Michigan.

Department of Fisheries and Forestry,

M. A. Hulme

Forest Products Laboratory, Ottawa.

Received September 19, 1969.

${ }^{1}$ Leutritz, J., Bell Syst. Tech. J., 25, 102 (1946).

${ }^{2}$ Gersonde, M., Holtzforschung, 12, 11 (1958).

${ }^{3}$ Gersonde, M., Holtzforschung, 12, 104 (1958).

${ }^{4}$ Henningsson, B., Studia Forestalia Suecica, 34 (1965).

${ }^{5}$ Wilcox, W. W., US Forest Service Research Paper FPL 70 (US Dept. of Agriculture, Forest Products Lab., Madison, Wisconsin, 1968).

Standard Method for Laboratory Test of Natural Decay Resistance of Woods. Design 2017-63 (American Society for Testing and Materials, 1965).

'Robertson, N. F., in The Fungi (edit. by Ainsworth, G. C., and Sussman, A. S.), 1, 613 (Äcademic Press, New York and London, 1965).

8 Thompson, J. H., Cowling, E. B., and Ross, E. W., Canad. J. Bot., 46 , $1533(1968)$.

${ }^{2}$ Humphrey, C. J., and Siggers, P. V., J. Agric. Res., 47, 997 (1933).

${ }^{10}$ Standard Method for Testing Wood Preservatives by Laboratory Soil-Bloch Culture. Design 1413-61 (American Society for Testing and Materials, 1961).

\section{Bacterial Mechanism of Gley Formation in Artificially Submerged Soil}

WHEN a soil is flooded or kept waterlogged, iron reduction and gleying begin within a few weeks. So far only organic ligands from various litters have been found to be capable of reducing and bleaching ferric compounds in soil during gleying ${ }^{1,2}$, but the involvement of certain unknown iron reducing bacteria seems to be more likely, for iron reduction has been found to stop in a submerged soil when bacterial inhibitors are added ${ }^{3}$. Aerobic as well as anaerobic bacteria, capable of reducing ferric oxide, have been abundant in the soils studied, whether gleying was detectablo or not, ${ }^{4}$. As far as gleying is concerned, the most important iron reducing bacteria are likely to be the anaerobic, nitrogen-fixing clostridia, with properties that would suit them to the poor and anaerobic conditions of gleyed subsoils. If these nitrogen fixers are implicated in gleying, they should be able to reproduce the characteristic features of gleying, even in laboratory conditions.

I have tested this idea in a model system designed to simulate conditions favourable for the formation of gleys. Approximately $10 \mathrm{~g}$ of a red sift soil containing ferric oxide were submerged in $6 \times 1$ inch boiling tubes with $30 \mathrm{ml}$. of a nitrogen-free solution of glucose and mineral salts ${ }^{6}$, autoclaved for $15 \mathrm{~min}$ and inoculated with a culture of the butyric-butyl group of clostridia. This inoculum was prepared by adding about $0.2 \mathrm{~g}$ of a top soil into $7 \mathrm{ml}$. of the nitrogen-free glucose broth supplemented with $0 \cdot 1$ per cent finely powdered, reagent grade $\mathrm{Fe}_{2} \mathrm{O}_{3}$. When heavy gas production was observed (recorded in an inadvertently inserted Durham vial), I tested for iron reduction ${ }^{4}$ (to demonstrate iron reducing ability). A fresh tube was inoculated with $1 \mathrm{ml}$. of the suspension, pasteurized $(15 \mathrm{~min}$ at $\left.80^{\circ} \mathrm{C}\right)$ and incubated for at least $48-72 \mathrm{~h}\left(30^{\circ} \mathrm{C}\right)$. This enrichment procedure was repeated ten times and the resulting culture of the bacteria was used to inoculate the model system by stabbing a pipette carefully into the soil material. The tubes were kept under nitrogen in an anaerobic jar at $30^{\circ} \mathrm{C}$.

Within a few hours of incubation, gas was coming from the soil, demonstrating active fermentation. The first gley spots, scattered through the upper part of the soil, appeared after about 12 days. These small, local areas of grey discoloration increased with time and joined together in the upper zone of the column of soil. In the early stages of development, the soil had the typical mottling found in gleyed soils. By the time fermentation had ceased, nearly all the soil surface was ash-grey and reduced. The intensity of discoloration decreased with increasing depth.

These observations suggest that the formation of gley in waterlogged soils may, at least in part, be caused by iron-reducing bacteria of the Clostridium butyricum group. J. C. G. Otrow

Institut für Landwirtschaftliche Mikrobiologie,

Justus Liebig-Universitä.t, Giessen.

Received September 23, 1969.

' Bloomfield, C., J. Soil Sci., 2, 196 (1951).

2 Lossaint, P., Ann. Agron., 10, 369 (1959).

${ }^{3}$ Kamura, T., Takai, Y., and Ishikawa, K., Soil Sci. Plant Nutrit., 9, 171 (1963).

${ }^{4}$ Ottow, J. O. G., Z. Allg. Mikrobiol., 8, 441 (1968).

s Ottow, J. C. G., Zbl. Bakt. Parasitk. Abt. II, 123, 600 (1969).

${ }^{8}$ Augier, J., Ann. Inst. Pasteur, 92,817 (1957).

\section{Tin in Organisms and Water in the Gulf of Naples}

Thene are few reported measurements of the concentration of tin in seawater or the tissues of marine organisms. Noddack and Noddack ${ }^{1}$ gave a value of $3 \mu \mathrm{g}$ of $\mathrm{Sn} / \mathrm{l}$. for water from the Gullmarfjord, Sweden, and Shimizu and Ogata $^{2}$ reported a concentration of $1.8 \mu \mathrm{g} / \mathrm{l}$. for water from the Japan coast. Hamaguchi et al. ${ }^{3}$, using neutron activation analysis, found between 0.30 and $1.22 \mathrm{\mu g} / \mathrm{l}$. (mean $0.81 \mu \mathrm{g} / \mathrm{l}$.) in samples from the north-west Pacific. The most reliable information about the occurrence of tin in organisms was provided by Black and Mitchell ${ }^{4}$ for marine algae which contained 0.03-3.8 $\mu \mathrm{g}$ of Sn/g dry weight, and by Hamaguchi et al. ${ }^{3}$, who found $0 \cdot 7-2.9 \mu \mathrm{g} / \mathrm{g}$ dry weight in three animal species from Tokyo Bay.

The chief problems of obtaining reliable information about tin in seawater are the lack of sensitive, specific analytical procedures, and the difficulty of excluding contamination from apparatus, reagents and the environment, particularly during the initial stages of concentration and separation. This communication describes the application of a sensitive spectrophotometric procedure $^{5}$ to the measurement of tin in seawater and marine organisms from the Gulf of Naples, with a novel method for concentrating tin from seawater. Work is in progress on the occurrence of tin in marine materials from other sources.

Surface seawater (salinity $37 \cdot 29 \%$ ) was collected $4 \mathrm{~km}$ from Cape Posillipo on May 7, 1969, by immersing polyethylene bottles that had been washed in acid. The total sample of about $10 \mathrm{~kg}$ was weighed and ${ }^{113} \mathrm{Sn}$ in hydrochloric acid was added for subsequent determination of the tin recovered. The sample was adjusted to $p \mathrm{H} 9.6$ by adding a dilute solution of ammonia, and the water was pumped through a polyethylene column packed with 'Spectrosil' quartz wool at a rate of $250 \mathrm{ml}$./ h using a multi-channel peristaltic pump. Each bottle and column 